\title{
Effect Combination of Inspiratory Muscle Training and Aerobic Exercise on Cardiopulmonary Endurance and Pulmonary Function in Systemic Lupus Erythematosus
}

\section{Irsan Agung Ramdhani ${ }^{1}$, Irma Ruslina Defi ${ }^{1}$, Dian Marta Sari ${ }^{1}$, Rachmat Gunadi Wachjudi ${ }^{1}$}

${ }^{1}$ Physical Medicine and Rehabilitation Department, Padjadjaran University, Hasan Sadikin General Hospital Bandung, Indonesia.

\begin{abstract}
Introduction: Systemic Lupus Erythematosus (SLE) is a chronic autoimmune disease which decreased cardiopulmonary endurance and pulmonary function are the clinical manifestations. Inspiratory Muscle Training (IMT) has never been studied before, but aerobic exercise is commonly studied in SLE patients. This study was conducted to know the combination effect of IMT and aerobic exercise in SLE patients.

Materials and methods: This study use quasi experimental design with pre and post-test approach. Fourteen SLE patients that included in the Lupus Low Disease Activity State (LLDAS) were given IMT and aerobic exercise for 8 weeks. Cardiopulmonary endurance is measured by 6-minute walk test (6MWT) and Metabolic Equivalents (METs), pulmonary function by Maximal Inspiratory Pressure (MIP), Forced Expiratory Volume in 1 second (FEV1), and Forced Vital Capacity (FVC).

Results: There is significant increase in pre and post intervention data, $397.45 \pm 49.34$ vs $427.50 \pm 48.67$ for 6MWT; $5.25 \pm 1.14$ vs $5.84 \pm 1.08$ for METs; $56.20 \pm 14.24$ vs $86.36 \pm 20.73$ for MIP; $68.00 \pm 10.71$ vs $72.90 \pm 11.30$ for FEV1; and $1.81 \pm 11.14$ vs $77.36 \pm 11.80$ for FVC.

Conclusion: The combination of IMT and aerobic exercise can increase cardiopulmonary endurance and pulmonary function in SLE patients.
\end{abstract}

Keywords: aerobic, inspiratory muscle training, lupus low disease activity state, maximal inspiratory pressure, metabolic equivalents, six-minute walk test. 


\section{ABSTRAK}

Background: Lupus Eritematosus Sistemik (LES) merupakan suatu penyakit autoimun kronis yang ditandai dengan adanya penurunan daya tahan kardiopulmonal dan fungsi paru sebagai manifestasi klinisnya. Penelitian mengenai Latihan Otot Inspirasi (LOI) belum pernah di lakukan sebelumnya, namun penelitian mengenai latihan aerobik cukup sering dilakukan pada pasien LES. Penelitian ini dilakukan untuk mengetahui efek kombinasi latihan LOI dan latihan aerobik pada pasien LES.

Bahan dan Metode: Penelitian ini menggunakan desain kuasi eksperimental dengan pendekatan pre dan post-test. Sebanyak 14 pasien LES yang dimasukkan dalam Lupus Low Disease Activity State (LLDAS) diberikan latihan LOI dan aerobik selama 8 minggu. Daya tahan kardiopulmonal diukur dengan tes berjalan 6 menit (6MWT) dan Metabolic Equivalents (METs), fungsi paru diukur dengan Tekanan Maksimal Inspirasi (MIP), Volume Ekspirasi Paksa dalam 1 menit (FEV1) dan Kapasitas Vital Paksa (FVC).

Hasil: Ditemukan peningkatan yang signifikan dalam intervensi data pre dan post-test, $397.45 \pm 49.34$ vs $427.50 \pm 48.67$ untuk $6 M W T ; 5.25 \pm 1.14$ vs $5.84 \pm 1.08$ untuk METs; $56.20 \pm 14.24$ vs $86.36 \pm 20.73$ untuk $M I P ; 68.00 \pm 10.71$ vs $72.90 \pm 11.30$ untuk FEVI; dan $1.81 \pm 11.14$ vs $77.36 \pm 11.80$ untuk FVC.

Kesimpulan: Kombinasi Latihan LOI dan aerobic dapat meningkatkan daya tahan kardiopulmonal dan fungsi paru pada pasien LES.

Kata Kunci: aerobik, latihan otot inspirasi, lupus low disease activity state, metabolic equivalents, tekanan maksimal inspirasi, tes berjalan 6 menit.

\section{Correspondent Detail:}

\section{Irsan Agung Ramdhani}

Email: irsanramdhani@gmail.com

Physical Medicine and Rehabilitation

Department, Padjadjaran University,

Hasan Sadikin General Hospital,

Bandung, Indonesia.

\section{INTRODUCTION}

Incidence and prevalence of Systemic Lupus Erythematosus (SLE) vary widely depending on demographics, environment and social exposure. In Asia, the annual incidence of SLE ranges from 2.8 to 8.6 per 100,000 person-years, with a prevalence of 26.5 to 103 per 100,000 people. ${ }^{1}$ SLE is an autoimmune disease that can affect various organs of the body, including the skin, joints, central nervous system, and kidneys. ${ }^{2}$ SLE can affect all organ systems, including the respiratory tract and skeletal muscles. Studies in people with SLE show fatigue and reduced cardiopulmonary endurance with lower aerobic capacity and muscle strength. ${ }^{2}$

Decreased aerobic capacity in patients with SLE is caused by deconditioning of peripheral muscles and inadequate oxygen uptake. ${ }^{3}$ Balsamo et al. show that SLE patients walk shorter distances on a 6-minute walking test (6MWT) than controls were matched for age, physical characteristics, and physical activity level (International Physical 
Activity Questionnaire/s-IPAQ). ${ }^{4}$ Colin et al. compared between patients with sedentary activity and SLE patients, which showed a reduced level of aerobic fitness in SLE patients, thereby decreasing exercise capacity. ${ }^{5}$ Amra et al. shows a decrease in Maximum Inspiratory Pressure (MIP), as well as Maximum Expiratory Pressure (MEP) in SLE patients, which can ultimately reduce Forced Vital Capacity (FVC). ${ }^{6}$

Pharmacological and non-pharmacological management in patients with SLE has been widely studied. This can be seen in several studies that have shown that aerobic exercise has a positive effect as adjuvant therapy in treating SLE patients. Exercise proven can increase maximal oxygen $\left(\mathrm{VO}_{2} \max \right)$, aerobic capacity, autonomic control of the heart, and quality of life in SLE patients. ${ }^{7}$ Study conducted with supervised cardiovascular exercise program show a significant increase in exercise tolerance, aerobic capacity, quality of life, and depression in patients with SLE. ${ }^{8}$ Another has shown that aerobic exercise, joint range of motion exercises, and muscle strengthening exercises are safe and do not worsen the activity of SLE. ${ }^{9}$

Inspiratory Muscle Training (IMT) is a method that aims to improve the strength and endurance of the diaphragm and accessory muscles, one of the muscle strengthening exercises. Taking voluntary inspirations against a resistive load across the complete range of vital capacity when at rest is typical of IMT. ${ }^{10}$ In Ankylosing Spondylitis, one of the autoimmune diseases, IMT significantly increases aerobic capacity, pulmonary function, and ventilation efficiency. ${ }^{11}$ However, in SLE patients has not been reported yet. IMT has also proven to increase cardiopulmonary endurance in healthy populations with a sedentary lifestyle, while in sick populations such as Multiple
Sclerosis, Sarcoidosis, and chronic kidney disease, it can improve lung function, quality of life, and reduce fatigue. ${ }^{11-15}$

According to the previous study, the effect of aerobic exercise on quality of life in SLE is better than muscle strengthening exercise. But, the effectiveness of aerobic exercise cannot prevent the changes in body muscle strength that can cause fatigue and low quality of life in SLE patients. Soriano et al. pointed out the importance of muscle-strengthening exercises because SLE patients tend to show lower muscle strength and are proven to be predictors of decreased functional capacity over time. ${ }^{16}$ The combination of aerobic exercise and IMT that one of musclestrengthening exercises in SLE not done yet.

The purpose of this study was to investigate the effects of aerobic exercise and inspiratory muscle training combination exercises that have the potential to increase cardiopulmonary endurance and pulmonary function in patients with SLE.

\section{MATERIALS AND METHODS}

This study design was quasi-experimental with pre and post-test. The study was conducted May 2019 - August 2019 at the Department of Physical Medicine \& Rehabilitation, Dr. Hasan Sadikin General Hospital, Bandung, Indonesia. This study has obtained ethical approval from the hospital ethics committee (ethical clearance number: LB.02.01/X.6.5/110/2019).

\section{Patients}

The target population was SLE patients who had routine medical treatment at Rheumatology Clinic, Department of Internal Medicine, Dr. 
Hasan Sadikin General Hospital, Bandung, Indonesia.

\section{Inclusion criteria}

To be included in this study, subjects should match the following criteria: female SLE patients aged 20-50 years, Low Lupus Disease Activity State (LLDAS) ${ }^{17}$ (SLE Disease Activity Index $\leq 4$, with no activity in major organ systems and no haemolytic anaemia or gastrointestinal activity; a current steroid dose $\leq 7.5 \mathrm{mg}$ daily), and normal body mass index.

\section{Exclusion criteria}

Exclusion criteria were history of heart and lung disease, surgery on the thoracic and/or abdominal site, involved in aerobic exercise and or muscle strengthening in the last six months. The elimination criteria was the subjects did not do exercise 3 times along the program.

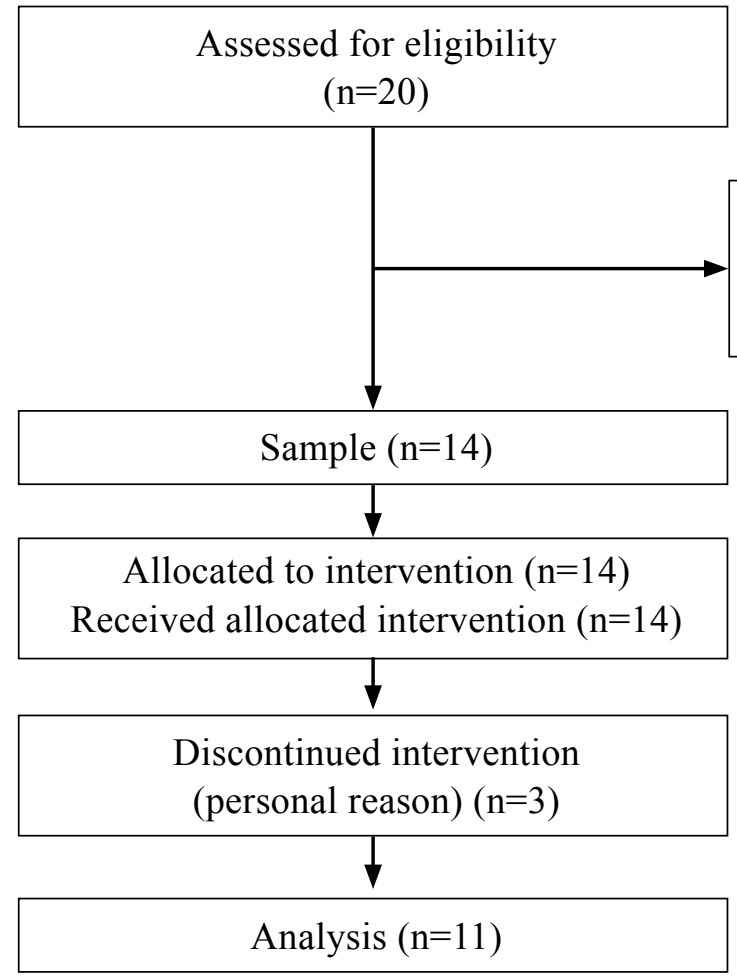

Excluded $(\mathrm{n}=6)$

Not Meeting inclusion criteria $(n=5)$

Decline to participate $(\mathrm{n}=1)$

Figure 1. Research pathway

\section{Intervention}

Interventions were aerobic exercise and inspiratory muscle strengthening three times a week in 12 weeks. Aerobic exercise was given at moderate intensity ( $40 \%$ of Heart Rate Reserve/HRR), 30 minutes duration, using the treadmill. Inspiratory muscle training was given at low intensity $(30 \%$ of MIP), five sets, ten repetitions per set, using Philips Respironics threshold IMT® (PT. Philips Indonesia Commercial, Jakarta Indonesia). The exercises were conducted on the same day with 1 hour resting time between exercises. 


\section{Outcomes}

Outcomes of this study were Maximal Inspiratory Pressure (MIP), Forced Expiratory Volume in 1 second (FEV1), and Forced Vital Capacity (FVC), which represents a pulmonary function, while cardiopulmonary endurance is measured by 6-minute walk test (6MWT) and Metabolic Equivalents (METs).

Measurement of MIP was performed using a Micro Respiratory Pressure Meter (MicroRPM Carefusion ${ }^{\circledR}$ from UK 232 Ltd, United Kingdom), FEV1 and FVC using spirometry, and cardiopulmonary endurance using a 6-minute walk test (6MWT). At the same time, metabolic equivalents (METs) was determined by predicted VO2max value using the Nury's formula. ${ }^{18}$

\section{Statistics Analysis}

The Shapiro-Wilk test was used to determine the normality of the variables. Data were analyzed using $\quad$ IBM ${ }^{\circledR} \quad$ SPSS ${ }^{\circledR}$ Statistics 24.0 version for windows from New York, United States, an increase between pre and post-test data was analyzed using paired t-test with the statistical significance was based on $p<0.05$. The sample size was obtained by the consecutive sampling method.

\section{RESULTS}

\section{Subject characteristic}

As shown in Table 1, the average age was 34 years old, and SLE patients were mostly found in the productive age group. There was no activity or involvement in the vital organ system (kidney, central nervous system, cardiopulmonary, vasculitis, fever) and without haemolytic anaemia or digestive system (MEX SLEDAI $\leq 4)$. Corticosteroid dose per day is $\leq 7.5 \mathrm{mg}$, in accordance with the LLDAS category.

Table 1. Subject Characteristics

\begin{tabular}{lc}
\hline \multicolumn{1}{c}{ Variable } & n $=\mathbf{1 1}$ \\
\hline Age $($ years $)($ mean \pm SD) & $34.18 \pm 9.92$ \\
Body weight (kilogram) $($ mean \pm SD) & $49.27 \pm 6.94$ \\
Body height (centimeter) $($ mean \pm SD) & $154.54 \pm 4.54$ \\
Body Mass Index (kilogram/meter2) $($ mean \pm SD) & $20.59 \pm 2.44$ \\
MEX SLEDAI (mean \pm SD) & $2.18 \pm 0.98$ \\
Corticosteroid dose (miligram/day) $($ mean \pm SD) & $4.54 \pm 0.93$ \\
\hline
\end{tabular}

Note: MEX SLEDAI = Mexican Systemic Lupus Erythematosus Disease Activity; $\mathrm{n}=$ number of subject; $\mathrm{SD}=$ standard deviation

\section{Effect of the combination of inspiratory muscle training and aerobic exercise on cardiopulmonary endurance}

Table 2 showed the increase of value in $6 \mathrm{MWT}$ after the combination of inspiratory muscle training and aerobic exercise was significant ( $\mathrm{p}<0.05$ ). Aerobic capacity (METs) increase significantly too $(\mathrm{p}<0.05)$ after administration of those combination exercises. 
Table 2. Comparative characteristic of 6MWT and aerobic capacity pre and post-intervention

\begin{tabular}{lccc}
\hline \multicolumn{1}{c}{ Variable } & Pre Intervention & Post Intervention & p value \\
& $\mathbf{n = 1 1}$ & $\mathbf{n = 1 1}$ & \\
\hline 6MWT (meter) (mean \pm SD) & $397.45 \pm 49.34$ & $427.50 \pm 48.67$ & 0.003 \\
Aerobic capacity $(\mathrm{METs})($ mean $\pm \mathrm{SD})$ & $5.25 \pm 1.14$ & $5.84 \pm 1.08$ & $<0.001$ \\
\hline
\end{tabular}

Note: $\mathrm{n}=$ number of subject; $\mathrm{SD}=$ standard deviation; $*$ = significant if $\mathrm{p}$ value $<0.05$.
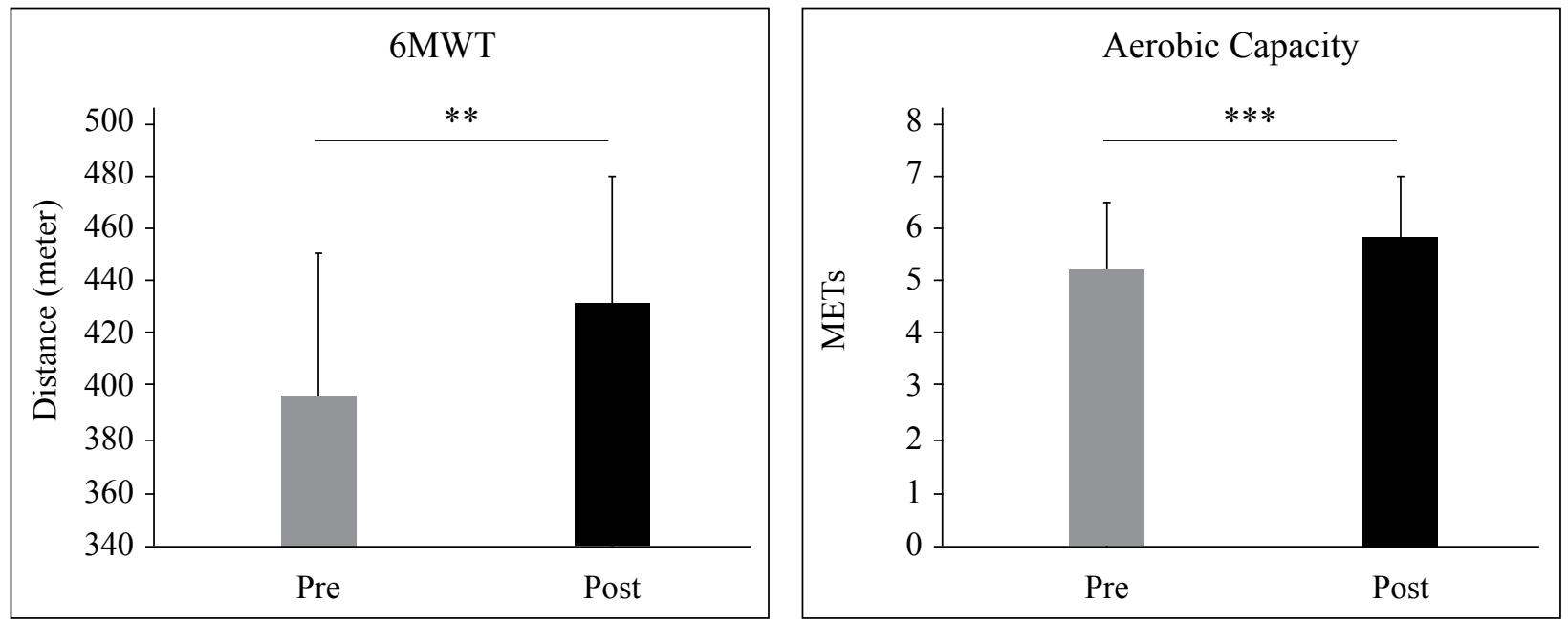

Figure 2. The effect of the combination of inspiratory muscle training and aerobic exercise on cardiopulmonary endurance according to 6-MWT (A) and aerobic capacity (B). Data presented as mean \pm SD. **: $\mathbf{p}<0.01 ; * * *: \mathbf{p}<0.00$

Effect of the combination of inspiratory muscle training and aerobic exercise on pulmonary function Table 3 showed the increase of FEV1, FVC, and MIP that representing a pulmonary function after administration of combination exercise. The results of this study are statistically significant, with $p$ value $<0.05$.

Table 3. Comparative characteristic of MIP, FEV1, and FVC pre and post-intervention

\begin{tabular}{lccc}
\hline \multicolumn{1}{c}{ Variable } & $\begin{array}{c}\text { Pre Intervention } \\
\mathbf{n}=\mathbf{1 1}\end{array}$ & $\begin{array}{c}\text { Post Intervention } \\
\mathbf{n}=\mathbf{1 1}\end{array}$ & \multirow{2}{*}{ p value } \\
\hline FEV1 (\%) (mean \pm SD) & $68.00 \pm 10.71$ & $72.90 \pm 11.30$ & $<0.001^{*}$ \\
FVC $(\%)($ mean \pm SD) & $71.81 \pm 11.14$ & $77.36 \pm 11.80$ & $<0.001^{*}$ \\
MIP $(\mathrm{cmH} 2 \mathrm{O})($ mean $\pm \mathrm{SD})$ & $56.20 \pm 14.24$ & $86.36 \pm 20.73$ & $<0.001^{*}$ \\
\hline
\end{tabular}

Note: $\mathrm{n}=$ number of subject; $\mathrm{SD}=$ standard deviation; $*=$ significant if $\mathrm{p}$ value $<0.05$.

\section{DISCUSSION}

Effect of combination of inspiratory muscle training and aerobic exercise on cardiopulmonary endurance
The effects of aerobic exercise and inspiratory muscle training combination exercises have potential to increase cardiopulmonary endurance in patients with SLE. In this study, the IMT and aerobic exercise combination significantly 
increased the cardiopulmonary endurance, shown by the distance of 6MWT from pre to postintervention by $7.56 \%$. The results of this study show the mean of $6 \mathrm{MWT}$ pre-intervention was $397.45 \pm 49.34$ meters that are in the range of very poor for the female subject ( $<405$ meters), according to the Nury's study. ${ }^{19}$ This results in line with Balsamo et al., which showed that SLE patients walked in shorter distances (598 \pm 45 meters) compared to the control group (642 \pm 14 meters). ${ }^{4}$ The different $6 \mathrm{MWT}$ results in this study and Balsamo's study because the characteristics subject in Balsamo's study was Brazilian premenopausal patients with lowactivity SLE (mean SLEDAI: $1.52 \pm 1.61$ ), while characteristics subject in this study was SLE patients with mean MEX-SLEDAI $2.18 \pm 0.98$ (score of 2-5 indicates the possibility of flare20). The difference in anthropometry between Brazilian (Caucasians) and Indonesians also affect $6 \mathrm{MWT}$ results. ${ }^{21}$

In this study, the METs values resulted from the conversion of the 6MWT by using Nury's formula. The METs, both pre and post-intrevention were in the moderate-intensity according to WHO (3-6 METs). Nury's formula includes several factors to convert 6MWT to METs, such as distance value of 6MWT, body height, body weight, and gender. ${ }^{18}$ These factors therefore could influence the VO2max prediction value, so METs value in the moderate intensity.

The difference value of METs that was not too high from pre and post-intervention, can be caused by the intensity of aerobic exercise. The American College of Sport Medicine explains that the principle of overload training is needed to produce an increase in the body's physiological parameters. Training below the minimum intensity or at an individual's threshold is not sufficient to produce it. ${ }^{22}$

Interactions between heart organs, lungs, and peripheral muscles affect cardiopulmonary endurance. Decreased cardiopulmonary endurance in SLE can be caused by vasculopathy as a form of vascular involvement in SLE that affect tissue oxygenation. Vasculopathy cause disruption of $\mathrm{O}_{2}$ transport to locomotor muscles or diffusion of $\mathrm{O}_{2}$ from muscle capillaries to the mitochondria during exercise or physical activity. Vasculopathy in SLE is commonly found in the kidneys, but extra-renal vasculopathies are also found involving peripheral blood vessels. ${ }^{23,24}$ Decreased cardiopulmonary endurance also can be affected by inefficient ventilation. Prado et al. showed inefficient ventilation during CPET with a treadmill in SLE patients compared to healthy controls. This results in vasoconstriction of the peripheral muscles via supraspinal reflex. The correlation of respiratory muscles and peripheral muscles is called the metaboreflex, as a result of the accumulation of metabolites in the respiratory muscles when muscle fatigue occurs. This can limit blood flow to the extremities, resulting in decreased exercise tolerance, aerobic capacity, and cardiopulmonary endurance. ${ }^{25,26}$

\section{Effect of the combination of inspiratory muscle training and aerobic exercise on pulmonary function}

Pulmonary function can be determined by FEV1 $(\%)$, and FVC (\%) value. This study showed a significant increase in FEV1, FVC and MIP after giving combination exercise. Until now there has been no research that study about IMT in SLE patients or their combination with aerobic exercise. But, several studies of inspiratory muscle training give good results in healthy 
populations, as well as sick populations suffering from autoimmune diseases such as Multiple Sclerosis and Sarcoidosis. ${ }^{11-15}$ The principle of specific and overload in exercise are the basis of IMT in this study. The exercise regimen can increase the proportion of muscle fibres and the recruitment of motor units. Better inspiratory muscle strength can increase the rate and depth of respiration, thereby increasing the values of FEV1, FVC, oxygen consumption, and diffusion rate. ${ }^{11,16,26,27}$

Comparing to other study, subject in this study have low values in FEV1, FVC, and MIP preintervention. According to Hussain's research, subject in this study shows the low FEV1 and FVC pre-intervention values $(68.00 \pm 10.714$ and $71.81 \pm 11.142$ ), if compared with healthy controls in Hussain's research (88.43 \pm 6.90 and $94.26 \pm 7.22)$. FEV1 and FVC in SLE patients depend on the duration of disease, the longer duration of disease, the lower the FEV1 and FVC values. ${ }^{28}$ MIP pre-intervention also in low value if compared to the normal value in healthy women who age 18-49 years old by Pessoa et al. (89.0$97.0 \mathrm{cmH} 2 \mathrm{O}) .{ }^{29}$

Guleria et al. showed that lung disorders can occur due to the role of immune complexes, vasculitis from alveolar capillaries and alveolar damage due to infectious processes. Other studies have shown that there is a reduction in mobility of the chest wall caused by weakness of respiratory muscles, thereby affecting pulmonary air volume flow. Decreased chest wall mobility is considered a factor that decreases lung function. ${ }^{30}$ Jakati et al. study showed that there was histological evidence of myositis found in $46.66 \%$ of SLE patients, which is type 2 muscle atrophy in most SLE patients. ${ }^{31}$
Another mechanism that affects low muscle strength is the use of corticosteroid drugs which is the treatment for SLE. The research of Wang et al. showed that glucocorticoids increase myostatin protein as a negative regulator of skeletal muscle growth. ${ }^{32}$ Amirouche et al. found that over-expression of myostatin can suppress muscle protein synthesis by inhibiting the mTOR pathway (mammalian target of rapamycin), that plays a role in the regulation of skeletal muscle hypertrophy. ${ }^{33}$

\section{Limitation and strength}

Our study did not limit the physical activity and duration of disease (SLE) of the subjects, that can be affect the cardiopulmonary endurance and pulmonary function in patients with SLE. Further research is needed that prescribes aerobic exercise with a higher intensity, so that a better cardiopulmonary endurance can be obtained in SLE.

\section{CONCLUSION}

The combination of inspiratory muscle training and aerobic exercise affect the cardiopulmonary endurance and pulmonary function in SLE patients. Cardiopulmonary endurance and pulmonary function were increased after the combination exercises.

\section{Acknowledgement and/or disclaimers, if any}

There is no conflict of interest, none of the authors have any conflicts of interest to declare. 


\section{REFERENCES}

1. Barber MRW, Drenkard C, Falasinnu T, Hoi A, Mak A, Kow NY, et al. Global epidemiology of systemic lupus erythematosus. Nat Rev Rheumatol 2021; 17: 515-32.

2. Kaul A, Gordon C, Crow MK, Touma Z, Urowitz $\mathrm{MB}$ et al. Systemic lupus erythematosus. Nat Rev Dis Primers 2016; 2: 16039.

3. Houghton KM, Tucker LB, Potts JE, Mckenzie DC. Fitness, fatigue, disease activity, and quality of life in pediatric lupus. Arthritis Rheumatol 2008; 59: 537-45.

4. Balsamo S, Cunha Nascimento D da, Tibana RA, de Santana FS, da Mota LMH, SantosNeto LLD. The quality of life of patients with lupus erythematosus influences cardiovascular capacity in 6-minute walk test. Rev Bras (Reumatol English Edition) 2013; 53: 75-87.

5. Tench C, Bentley D, Vleck V, McCurdie I, White P, D'Cruz D. Aerobic fitness, fatigue, and physical disability in systemic lupus erythematosus. J Rheumatol 2002; 29: 474-81.

6. Amra B, Mirzaei MR, Bonakdar ZS, Golshan M. Respiratory muscle function and spirometry in patients with systemic lupus erythematosus. Tanaffos 2006; 5(4):53-8.

7. Perandini LA, Sales-de-Oliveira D, Mello SBV, Camara NO, Benatti FB, Lima FR, et al. Exercise training can attenuate the inflammatory milieu in women with systemic lupus erythematosus. J Appl Physiol 2014; 117: 639-47.

8. Carvalho MRP de, Sato EI, Tebexreni AS, Heidecher RTC, Schenkman S, Neto TLB. Effects of supervised cardiovascular training program on exercise tolerance, aerobic capacity, and quality of life in patients with systemic lupus erythematosus. Arthritis Rheumatol 2005; 53: 838-44.
9. Wu M-L, Yu K-H, Tsai J-C. The effectiveness of exercise in adults with systemic lupus erythematosus: a systematic review and metaanalysis to guide evidence-based practice: meta-analysis of exercise in SLE. Worldviews Evid Based Nurs 2017; 14: 306-15.

10. lli SK, Held U, Frank I, Spengler CM. Effect of respiratory muscle training on exercise performance in healthy individuals: a systematic review and meta-analysis. Sports Med 2012; 42(8): 707-24.

11. Jakhotia K, Jain N, Retharekar S, Shimpi A, Rairikar S, Shyam AK, et al. Effect of inspiratory muscle training (IMT) on aerobic performance in young healthy sedentary individuals. J Med Thesis 2014; 2(3): 21-5

12. Drăgoi R-G, Amaricai E, Drăgoi M, Popoviciu $\mathrm{H}$, Avram C. Inspiratory muscle training improves aerobic capacity and pulmonary function in patients with ankylosing spondylitis: a randomized controlled study. Clin Rehabil 2016; 30: 340-6.

13. Pfalzer L, Fry D. Effects of a 10-week inspiratory muscle training program on lowerextremity mobility in people with multiple sclerosis: a randomized controlled trial. Int $\mathbf{J}$ MS Care 2011; 13: 32-42.

14. Karadall MN, Bo nak-Guclu M, Camc o lu B, Kokturk N, Turkta H. Effects of inspiratory muscle training in subjects with sarcoidosis: a randomized controlled clinical trial. Respir Care 2016; 61: 483-94.

15. de Medeiros AIC, Fuzari HKB, Rattesa C, Brandão DC, de Melo Marinho PÉ. Inspiratory muscle training improves respiratory muscle strength, functional capacity and quality of life in patients with chronic kidney disease: a systematic review. J Physiother 2017; 63: 76-83.

16. Soriano-Maldonado A, Vargas-Hitos J, Sabio 
J. Cardiovascular training vs. resistance training for improving quality of life and physical function in patients with systemic lupus erythematosus: a randomized controlled trial: comments on the article by abrãhao et al. Scand J Rheumatol 2016; 45: 253-4.

17. Franklyn K, Lau CS, Navarra SV, Louthrenoo W, Lateef A, Hamijoyo L, et al. Definition and initial validation of a Lupus Low Disease Activity State (LLDAS). Ann Rheum Dis $2015 ; 8$.

18. Nusdwinuringtyas N, Widjajalaksmi W, Bachtiar A. Healthy adults maximum oxygen uptake prediction from a six-minute walking test. Med J Indonesia 2011; 195.

19. Nusdwinuringtyas N. Six minute walking distance cut-off point in Indonesian (Mongoloid) population. J Indon Med Assoc $2018 ; 6$.

20. Khanna S, Pal H, Panday R M, Handa R. The relationship between disease activity and quality of life in systemic lupus erythematosus. Rheumatol (Oxford) 2004; 43(12): 1536-40

21. Enright P L, McBurnie M A, Bittner V, Tracy RP, McNamara R, Arnold A, et al. The six min walk test: a quick measure of functional status in elderly adults. Chest 2003; 123 : 387 98

22. Riebe D, Ehrman JK, Liguori G, Magal M. ACSM's guidelines for exercise testing and prescription. Tenth edition. Wolters Kluwer: Philadelphia, 2018.

23. Silva AG PD. Impaired aerobic capacity in systemic lupus erythematosus patients: what are the physiological mechanisms. Rheumatology (Sunnyvale) 2015; s6.

24. Waki D, Onishi A, Morinobu A. Large vessel vasculopathy in a patient with systemic lupus erythematosus: a case report. J Med Case Reports 2019; 13: 189.

25. do Prado D, Gualano B, Miossi R, Lima F, Roschel H, Borba E, et al. Erratic control of breathing during exercise in patients with systemic lupus erythematosus: a pilot-study. Lupus 2011; 20: 1535-40.

26. Harms CA. Insights into the role of the respiratory muscle metaboreflex. J Physiol 2007; 584: 711.

27. Kisner C, Colby LA. Therapeutic exercise: foundations and techniques. 6th ed. F.A. Davis: Philadelphia, 2012.

28. Hussain D, Begum S, Ali T, Ahmed M, Farzana R. Fvc, Fev1 and Fev1/Fvc \% in female SLE patients and their relationship with duration of the disease. Medical Today 2014.

29. Pessoa IS, Parreira VF, Fregonezi G, Chung F. Reference values for maximal inspiratory pressure: A systematic review. Can Respir J 2014; $21: 8$.

30. Guleria R, Pangtey G. Lung in SLE. Indian J Rheumatol 2007; 2(4):131-2.

31. Jakati S, Rajasekhar L, Uppin M, Challa S. SLE myopathy: a clinicopathological study. Int J Rheum Dis 2015; 18: 886-91.

32. Wang R, Jiao H, Zhao J, Wang X, Lin H. Glucocorticoids enhance muscle proteolysis through a myostatin-dependent pathway at the early stage. PLoS One 2016; 11.

33. Amirouche A, Durieux A-C, Banzet S, Koulmann N, Bonnefoy R, Mouret C, et al. Down-regulation of akt/mammalian target of rapamycin signaling pathway in response to myostatin overexpression in skeletal muscle. Endocrinology 2009; 150: 286-94. 